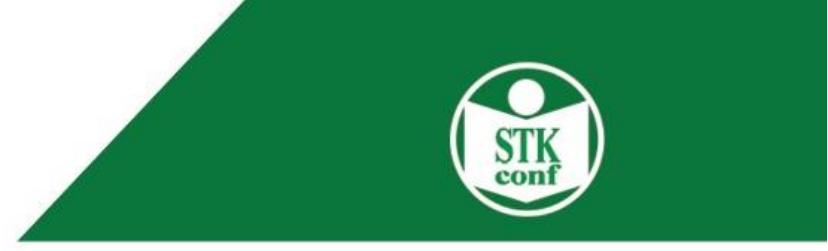

15-17 November 2019

Rotterdam, Netherlands

\title{
Effect of Synthesis Parameters on Thermal Behaviour and Crystalline Structures of Calcium Silicate Minerals
}

\author{
Buse Bozan $^{1}$ and Suna BALCI ${ }^{1}$ * \\ ${ }^{I}$ Gazi University, Engineering Faculty, Chemical Engineering Department, Ankara, Turkey
}

\begin{abstract}
.
Calcium silicates are porous, large surface area ultra-light minerals, whose diversity comes from close $\mathrm{Ca} / \mathrm{Si}$ ratios. Anhydrate calcium silicate $(\mathrm{C}-\mathrm{S})$ wollastonite and hydrate calcium silicates $(\mathrm{C}-\mathrm{S}-\mathrm{H})$ xonotlite and tobermorite are common varieties. The structures whose economic production is limited are widely used as heat insulation and fire resistant especially in places that require special shaped passive fire protection (PFP) plate. In use as cement additive, in addition to its effects on the strength properties of concrete, it also creates serious effects especially on the hydration process. By using $\mathrm{CaO}$ as a calcium and silica fume as a silica sources, with different $\mathrm{Ca} / \mathrm{Si}(0.83,1.00)$ and water/solid $(10,15)$ ratios in synthesis suspensions, directly or after the 4 hour pre-reaction under different temperature $\left(40{ }^{\circ} \mathrm{C}<\mathrm{T}\right.$ $<80^{\circ} \mathrm{C}$ ) synthesis of calcium silicate structures were carried out at an autogenous pressure of $200{ }^{\circ} \mathrm{C}$ applying or non-applying filtration after the pre-reaction. The products obtained were dried at room temperature, in oven at $60{ }^{\circ} \mathrm{C}$ and $-110{ }^{\circ} \mathrm{C}$ freeze-drying techniques. Higher mass loss was observed with synthesis at $80{ }^{\circ} \mathrm{C}$ pre-reaction temperature and tobermorite phase synthesis condition. The removal of structural water and $-\mathrm{OH}$ which took place above $250 \mathrm{oC}$ was found more tobermorite phase synthesis feed ratio sample. Typical C-S-H crystal peaks were detected in X-ray diffraction patterns. The decomposition of calcium hydrosilicate crystals in $320-600{ }^{\circ} \mathrm{C}$ and phase transforms between $800-875^{\circ} \mathrm{C}$ had been observed. The increase in success of xonotlite synthesis with pre-reaction temperatures was seen in X-ray diffraction peaks. The slight decreases in the descriptive peaks intensities were observed for samples synthesized at 40 and $80{ }^{\circ} \mathrm{C}$ pre-reaction temperatures and calcined at $300{ }^{\circ} \mathrm{C}$, while even the most severe peak decreased significantly in samples calcined at $700{ }^{\circ} \mathrm{C}$.
\end{abstract}

Keywords: xonotlite; tobermorite; thermal strength; mechanical strength; crystallinity

\section{Introduction}

While thermal insulation which is a necessity for building construction industry is generally covered by the petroleum derived plastic materials (EPS, XPS and polyurethane foam etc.), the fire insulation which is required by the industrial structures is provided either fibrous layered wool (glass wool, stone wool) or ceramic fiber type materials. Although plastic type thermal insulation materials have a low thermal conductivity, they have the disadvantage of being 


\section{$4^{\text {th }}$ International Conference On Applied Research In SCIENCE, TECHNOLOGY \& KNOWLEDGE}

15-17 November 2019

Rotterdam, Netherlands

dependent on oil and have disadvantages such as being flammable. Rockwool and similar inorganic materials with high fire resistance requires costly transport and construction operations due to their heavy weight. On the other hand light structures stand out as a cement additive. The importance of using light porous inert alternatives both as insulation and as cement additive material emerges $[1,2]$.

Calcium silicates (C-S) structures with high porosity, low density are used in heat insulation due to their light weight and high mechanical strength, while they are used as shaped materials for fire protection due to their high thermal resistance up to $1000{ }^{\circ} \mathrm{C}$ [3]. They are used in passive fire protection (PFP) as an additive material or specially shaped product to achieve the desired purpose [4]. In use as a cement additive, it creates positive effects on the hydration and hardening processes in addition to it affects the strength properties of concrete. In the hardening process of concrete, C-S-H forms a network with other compounds and contributes to hardening. In the cooling process, as the C-S-H and C-S formation increases, the strength of the concrete increases. As the result of the mineral admixtures are slow, the strength of the concrete containing pozzolonic material continues to last longer [5].

Calcium silicate minerals, whose diversity depends on close $\mathrm{Ca} / \mathrm{Si}$ ratios, exist in anhydrate $(\mathrm{C}$ $\mathrm{S})$ and hydrate $(\mathrm{C}-\mathrm{S}-\mathrm{H})$ forms. The most common forms are wollastonite $(\mathrm{Ca} / \mathrm{Si}: 1.00)$ and tobermorite $(\mathrm{Ca} / \mathrm{Si}: 0.83)$ group minerals [6]. The wollastonite group which has the anhydrate form wollastonite $1 \AA\left(\mathrm{CaSiO}_{3}\right)$ and the hydrate form xonotlite $\left(\mathrm{Ca}_{6} \mathrm{Si}_{6} \mathrm{O}_{17}(\mathrm{OH})_{2}\right)$ are widely used in the industry. With different length/diameter ratios, wollastonite can replace the short fiber mineral filler and other synthetic crystals with its needle structure support [7]. Xonotlite which has lower specific gravity than wollastonite, has high surface area, thermal resistance, low specific gravity, low thermal conductivity properties.

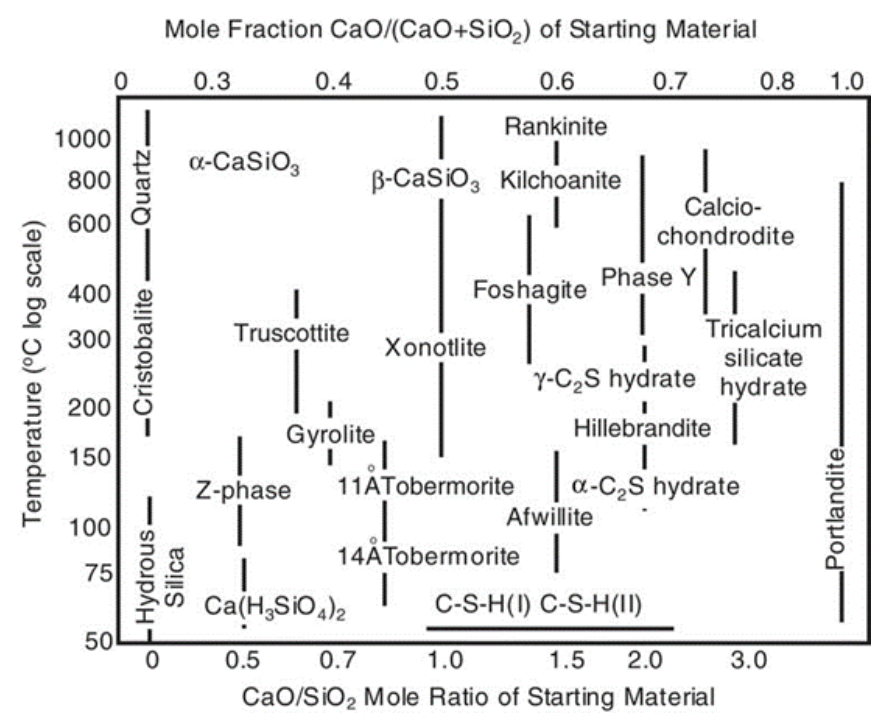

Figure 1. Variations of calcium silicate phases with feed ratio and synthesis temperature [8].

Synthetic C-S structures are preferred both their uniform structure and elimination of dangerous impurities. The final product diversity in calcium silicate synthesis is highly dependent on the molar ratios $(\mathrm{Ca} / \mathrm{Si})$ and temperature of the starting materials. In the graph 


\section{$4^{\text {th }}$ International Conference On Applied Research In SCIENCE, TECHNOLOGY \& KNOWLEDGE}

15-17 November 2019

Rotterdam, Netherlands

below, calcium silicate hydrate phases which may occur according to synthesis conditions are given in different $\mathrm{CaO} / \mathrm{SiO}_{2}$ and $\mathrm{CaO} / \mathrm{CaO}+\mathrm{SiO}_{2}$ molar ratios from $50{ }^{\circ} \mathrm{C}$ to $1000{ }^{\circ} \mathrm{C}$ (Figure 1). Those with high potential for isolation are aqueous calcium silicate $(\mathrm{C}-\mathrm{S}-\mathrm{H})$ xonotlite and tobermorite. Xonotlite can be synthesized at low temperature, so energy cost is low. It is preferred as an insulating material and especially in PFP board production [2].

\section{Experimental}

In the synthesis studies, $\mathrm{CaO}$ (Sciencelab, $\geq 99 \% \mathrm{CaO}$ ) and silica fume (Sigma, $\geq 99 \% \mathrm{SiO}_{2}$, $0.2-0.3 \mu \mathrm{m}$ ) were used as calcium and silicon sources, respectively. The $\mathrm{Ca} / \mathrm{Si}$ ratio in starting synthesis solution was kept either tobermorite (0.83) or xonotlite (1.00) feed conditions and water/solid (w/s) was changed as 10 and 15 . The resulting suspensions were subjected to prereaction at different temperatures $\left(40,60\right.$ and $\left.80^{\circ} \mathrm{C}\right)$ for 4 hours, after then the synthesis was completed at temperatures $200{ }^{\circ} \mathrm{C}$ in autoclave for 8 hours either applying or non-applying the vacuum filtration after pre-reaction. The synthesized products were dried at room temperature (15 days), $60{ }^{\circ} \mathrm{C}$ oven (72 hours) or freeze-dryer $\left(2\right.$ and $3 \mathrm{~h}$ at $-110{ }^{\circ} \mathrm{C}$ ) and subsequently calcined at either $300{ }^{\circ} \mathrm{C}$ or $700{ }^{\circ} \mathrm{C}$

Perkin Elmer Pyris 1 thermogravimetric analyzer was used to determine the thermal behavior in the air environment at a flow rate of $60 \mathrm{ml} / \mathrm{min}$ with a heating rate of $5{ }^{\circ} \mathrm{C} / \mathrm{min}$ within the range of room to $1000{ }^{\circ} \mathrm{C}$. X-ray diffraction patterns were taken for $2 \Theta$ values between Bragg angles of $5^{\circ}$ and $60^{\circ}$ using " $\mathrm{CuK \alpha}$ " beam source with a wavelength of 0.15418 $\mathrm{nm}$ at a scanning speed of $1 \%$ min using GNR APD 2000 PRO (40kV-30mA) device.

\section{Results and Discussion}

Thermal analysis was conducted to interpret the synthesis mechanism and determine the calcination temperature of calcium silicates according to the phase transitions. The TGA and DTA behaviors of the samples obtained under tobermorite and xonotlite feed conditions under pre-reaction conditions with a water/solid ratio of 15 at 60 and $80{ }^{\circ} \mathrm{C}$ are given in Figures 2 and 3 , respectively. The removal of moisture which was little for samples synthesized by tobermorite synthesis feed ratio, with a mass loss of about $6 \%$ up to $150{ }^{\circ} \mathrm{C}$ represents an endothermic reaction in the DTA curve in the range of $35-80{ }^{\circ} \mathrm{C}$. The mass loss between 150 $250{ }^{\circ} \mathrm{C}$ which was caused by inter-layer water remained constant after a $1 \%$ mass loss up to 170 ${ }^{\circ} \mathrm{C}$ under under tobermorite phase synthesis conditions, while this mass loss showed an endothermic peak range of $150-170^{\circ} \mathrm{C}$ in the DTA curve. After $150{ }^{\circ} \mathrm{C}$, higher mass loss was observed with synthesis at $80^{\circ} \mathrm{C}$ pre-reaction condition. The mass loss, which stand stationary up to $250{ }^{\circ} \mathrm{C}$, became clear evident. Samples synthesized by $80{ }^{\circ} \mathrm{C}$ and $60{ }^{\circ} \mathrm{C}$ pre-reaction conditions exhibited similar mass loss behavior up to $180^{\circ} \mathrm{C}$ and $330^{\circ} \mathrm{C}$, respectively. The mass loss after $250{ }^{\circ} \mathrm{C}$ was due to the removal of the structural water and $-\mathrm{OH}$, and the DTA curve gave an endothermic peak at $260^{\circ} \mathrm{C}$. For tobermorite phase synthesis feed ratio, mass losses up to $300{ }^{\circ} \mathrm{C}$ were higher than that of xonotlite due to the excess $-\mathrm{OH}$ and $\mathrm{H}_{2} \mathrm{O}$ groups in the structure. Samples with pre-reacted synthesis conditions of $60^{\circ} \mathrm{C}$ showed less mass loss up to $350{ }^{\circ} \mathrm{C}$ compared to the sample at the other temperature, after this temperature the mass loss became apparent. The peak range $\left(250-300{ }^{\circ} \mathrm{C}\right)$ exhibited the same thermal behavior under tobermorite and xonotlite synthesis conditions with the presence of endothermic reaction. After 


\section{$4^{\text {th }}$ International Conference On Applied Research In SCIENCE, TECHNOLOGY \& KNOWLEDGE}

15-17 November 2019

Rotterdam, Netherlands

$400{ }^{\circ} \mathrm{C}$, the mass loss of the samples synthesized at $60{ }^{\circ} \mathrm{C}$ pre-reaction temperature decreased again. It is known that $\mathrm{CaOH}$ dehydration occurs in the range of $420-540{ }^{\circ} \mathrm{C}$. The mass loss observed in low preheated synthesis under tobermorite synthesis conditions can be interpreted as the presence of significant $\mathrm{CaOH}$ impurity in the structure. After $700{ }^{\circ} \mathrm{C}$, the mass loss was reduced except for the samples in $80^{\circ} \mathrm{C}$ pre-reactions. The exothermic reaction in the wide peak range between $800-850{ }^{\circ} \mathrm{C}$ represents the transition to wollastonite $1 \AA$ phase $[7,9,10]$. Between $800-850{ }^{\circ} \mathrm{C}$, exothermic peaks caused by water loss from structural hydroxyls. In this temperature range, the loss of mass remained approximately constant for the synthesis rate where the $\mathrm{Ca} / \mathrm{Si}$ representing xonotlite was 1.00 , while in tobermorite synthesis conditions it was observed that the loss of water was higher with a small difference as expected from the structural formula derived from bound $\mathrm{H}_{2} \mathrm{O}$ or $-\mathrm{OH}$.

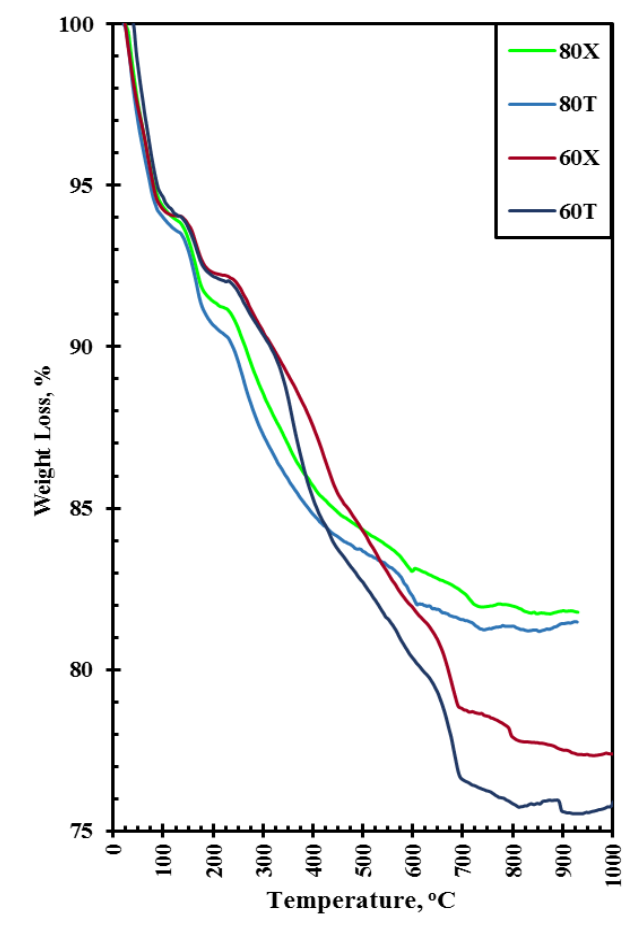

Figure 2. Termograms of calcium silicate samples synthesized at different prereaction temperatures under different feed ratios (w/s: 15 ; 80 and $60^{\circ} \mathrm{C}$ denote prereaction temperatures; $\mathrm{X}$ and $\mathrm{T}$ denote conditions of xonotlite and tobermorite synthesis feed ratios, respectively)

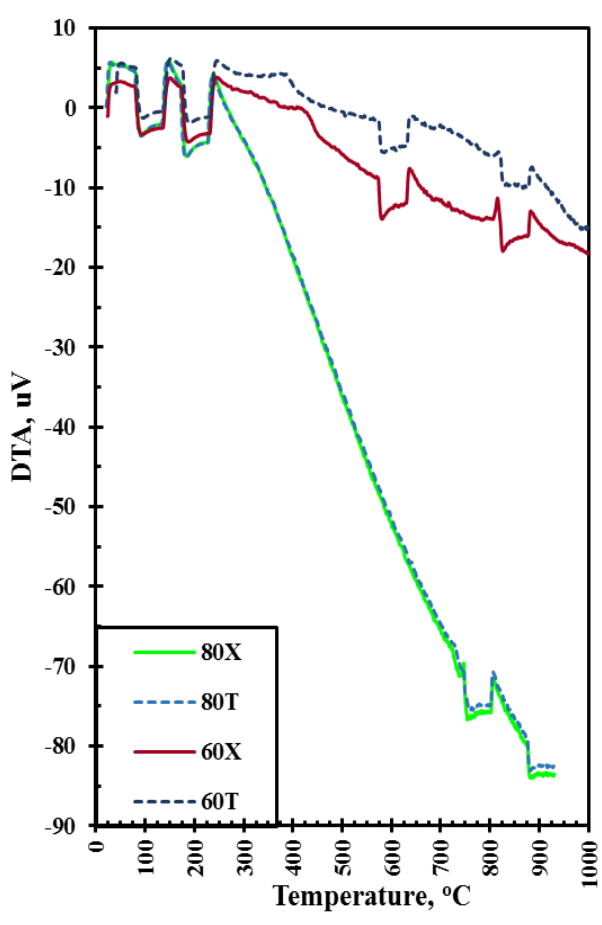

Figure 3. DTA curves of calcium silicate samples synthesized at different prereaction temperatures of under different feed ratios $(w / s=15 ; 80$ and 60 oC denote pre-reaction temperatures; $X$ and $T$ denote conditions of xonotlite and tobermorite synthesis feed ratios, respectively)

The thermal behavior of the samples showed that the removal of moisture and inter-layer water up to $250^{\circ} \mathrm{C}$, after which the bound water and $-\mathrm{OH}$ removal started, and became apparent after $300{ }^{\circ} \mathrm{C}$. It was seen that solid phase transformation occurs after $700{ }^{\circ} \mathrm{C}$. In order to evaluate the effect of structure formation, synthesis and extensive characterization studies were carried out by selecting calcination temperature as $300^{\circ} \mathrm{C}$ and $700{ }^{\circ} \mathrm{C}$.

Typical C-S-H crystal peaks were detected in X-ray diffraction patterns (Figure 4 and 5). It has been reported in the literature that the typical peak of the $\mathrm{C}-\mathrm{S}-\mathrm{H}$ mineral obtained under different synthesis conditions yields the most severe peak ( $\left./ / I_{0}: 100\right)$ at $20-35^{\circ}$ [11-13]. The 


\section{$4^{\text {th }}$ International Conference On Applied Research In SCIENCE, TECHNOLOGY \& KNOWLEDGE}

15-17 November 2019

Rotterdam, Netherlands

ascending peak in $2 \Theta$ range of $30-32^{\circ}$ represents the amorphous phase in the $\mathrm{C}-\mathrm{S}-\mathrm{H}$ structure $[8,14]$. In this study, peak behavior in peak range of $2 \Theta: \sim 28-30^{\circ}$ was observed in all XRD outputs with expanding peak in the same range. The success of xonotlite synthesis was observed to increase with an increase in pre-reaction temperature.
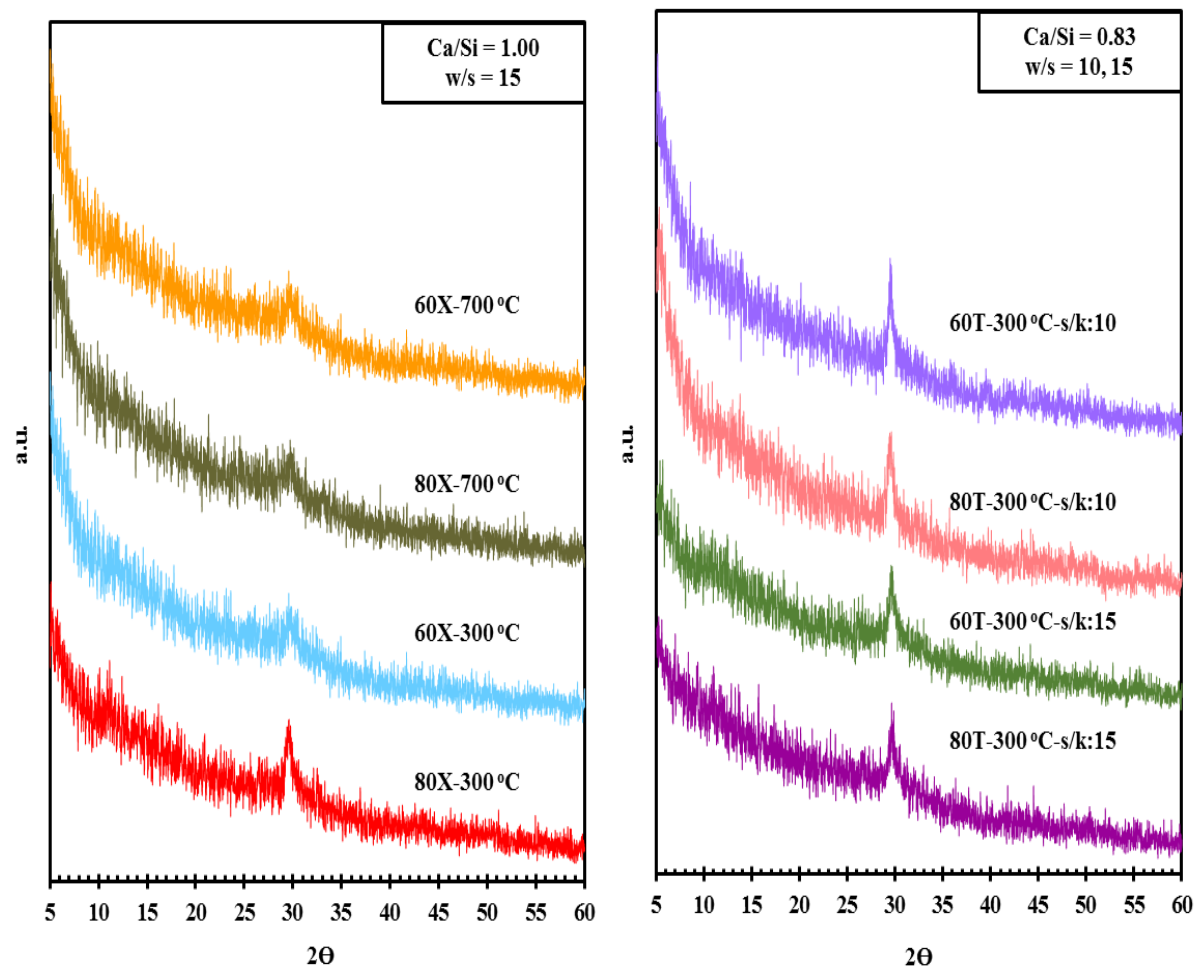

Figure 4. X-ray diffraction patterns of samples synthesized at different pre-reaction temperatures of under different feed ratios and different $w / s$ ratios $\left(80\right.$ and $60^{\circ} \mathrm{C}$ denote pre-reaction temperatures; $X$ and $T$ denote conditions of xonotlite and tobermorite synthesis feed ratios, respectively)

The highest peak $\left(\mathrm{I} / \mathrm{I}_{\mathrm{o}}: 100\right)$ defined in the literature for the tobermorite $(\mathrm{Ca} / \mathrm{Si}: 0.83)$ phase is given as $2 \Theta: 6-10^{\circ}[10,15]$. It is known that hkl planes exhibiting layered structure in crystal structures as seen SBA, MCM, clay are in $2 \Theta \leq 10$ regions [16, 17]. Grangeon et al. (2013) described 2Ө: $\sim 6^{\circ}, 16^{\circ}$ and $29.5^{\circ}$ peaks as 002,101 and 110 plane reflections, respectively [18]. The peak (2Ө: $\sim 6)$ of (002) plane reflection observed in the study was evaluated as the reflection of the layered structure of tobermorite (Figure 4). In the study conducted for w/s: 15 , $\mathrm{I} / \mathrm{I}_{\mathrm{o}}: 100$ peaks were clearly observed around $2 \Theta: \sim 6^{\circ}$ in all samples, while $\mathrm{I} / \mathrm{I}_{\mathrm{o}}: 65$ and $\mathrm{I} / \mathrm{I}_{\mathrm{o}}: 45$ peaks were occurred at 2Ө: $\sim 25^{\circ}$ and $\sim 29.75$ Bragg 's angles, respectively (Figure 5).

It was observed that the intensity of reflections of samples with $\mathrm{Ca} / \mathrm{Si}: 0.83$ decreased after calcination with $300{ }^{\circ} \mathrm{C}$. Although there was no big difference in calcined samples at $300{ }^{\circ} \mathrm{C}$, the peak intensities decreased as pre-reaction temperature increased for the calination temperature of $700{ }^{\circ} \mathrm{C}$. Due to the improvement in the crytalline properties with an increase of pre-reaction temperature, the syntheses were carried out at 60 and $80{ }^{\circ} \mathrm{C}$ with the ratio of s/k: 10. According to X-ray diffraction patterns, peak intensities of $\mathrm{s} / \mathrm{k}$ : 10 for tobermorite phase were found to be relatively high compared to syntheses with s/k: 15 (Figure 4). 


\section{$4^{\text {th }}$ International Conference On Applied Research In SCIENCE, TECHNOLOGY \& KNOWLEDGE}

15-17 November 2019

Rotterdam, Netherlands
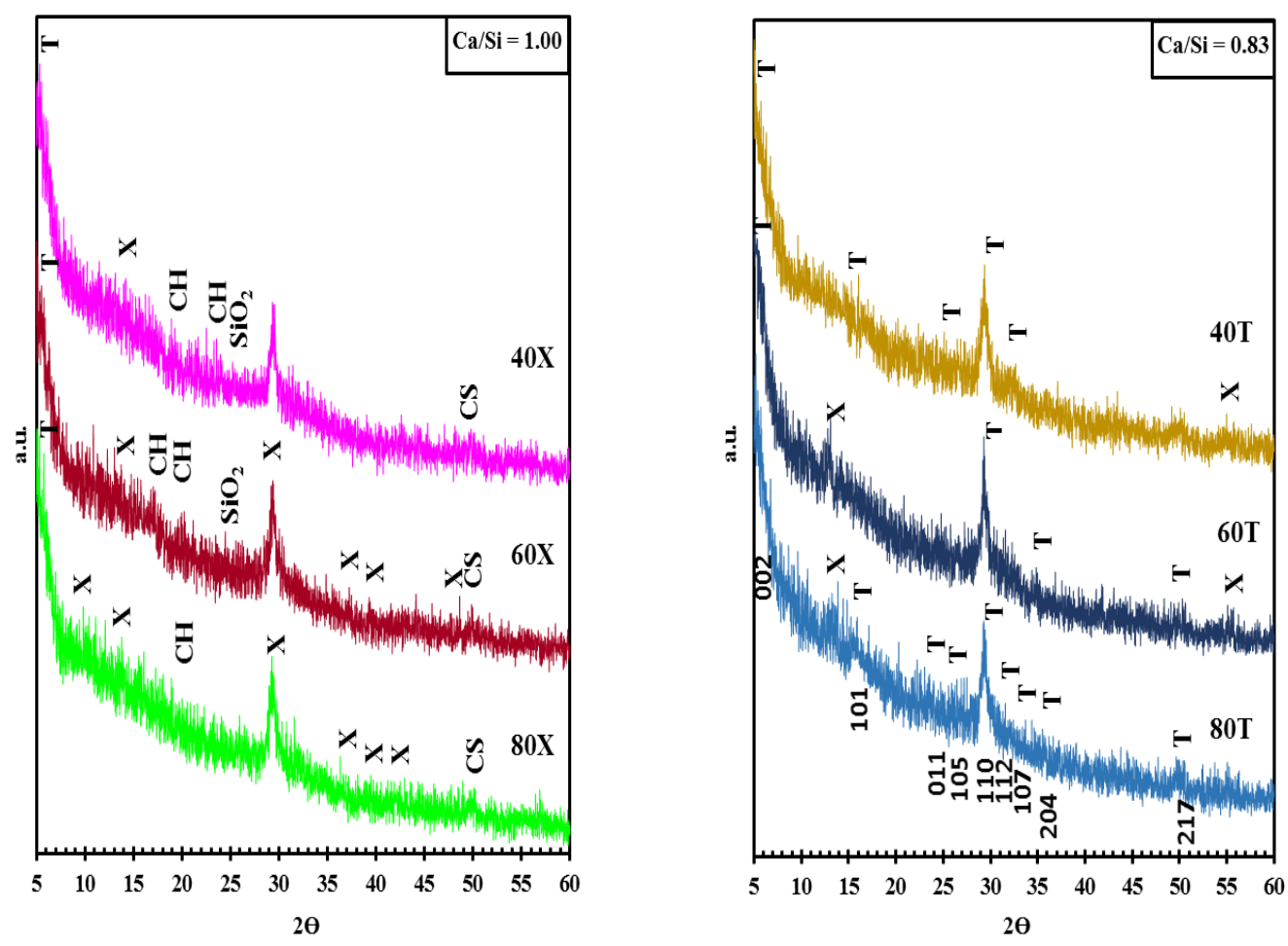

Figure 5. X-ray diffraction patterns of samples synthesized at different pre-reaction temperatures of under different feed ratios $\left(w / s=15 ; 80,60\right.$ and $40^{\circ} \mathrm{C}$ denote pre-reaction temperatures; $X$ and $T$ denote conditions of xonotlite and tobermorite synthesis feed ratios, respectively)

It has been reported in the literature that $\mathrm{I} / \mathrm{I}_{\mathrm{o}}: 100,65$ and 45 reflect planes of (002), (001), (110) $[15,18]$. For the $\mathrm{Ca} / \mathrm{Si}: 0.83$ ratio, the $(112)$ reflection $\left(2 \Theta: \sim 31^{\circ}\right)$ became slightly apparent. The peak $\mathrm{I} / \mathrm{I}_{0}: 13$ defined as plane reflection (107) was observed at an angle of $2 \Theta$ : $32^{\circ}$. In the sample synthesized with a ratio of $\mathrm{Ca} / \mathrm{Si}$ : 0.83 , the reflections of $6.31^{\circ}, 29.5^{\circ}, 16.1^{\circ}$, which are more pronounced, indicated the clarity of the tobermorite phase in the final product. In tobermolite synthesis conditions, peak density was found to be highest at $60{ }^{\circ} \mathrm{C}$ and relatively lower at $80{ }^{\circ} \mathrm{C}$ and $40{ }^{\circ} \mathrm{C}$ (Figure 5).

The most severe peak observed at $2 \Theta: 28.92^{\circ}$ is defined as $\mathrm{I} / \mathrm{I}_{\mathrm{o}}: 100$ peak for xonotlite synthesis condition $(\mathrm{Ca} / \mathrm{Si}$ : 1.00$)$ was lower than the one for tobermorite synthesis condition. Hsiang et al. (2015) reported that an increase in pre-reaction temperature increase mean chain length [19]. Unlike tobermorite, the highest peak at $80{ }^{\circ} \mathrm{C}$ was exhibited in accordance with the literature, while small decreases were observed regularly at 60 and $40^{\circ} \mathrm{C}$. For xonotlite $\mathrm{I} / \mathrm{I}_{\mathrm{o}}: 50$ peaks are given at $31.61^{\circ}$ and I/Io: 40 peaks are given at $33.19^{\circ}$. In the synthesis studies carried out in the literature, it is seen that peaks are exhibited at this angle and its vicinity. In the present study, the first peak was observed with a low intensity at $40{ }^{\circ} \mathrm{C}$ and $80{ }^{\circ} \mathrm{C}$ at an angle of $2^{\circ}$ : $32^{\circ}$ and for a pre-reaction temperature of $60^{\circ} \mathrm{C}$ it was not observed.

It was observed that peak intensities were decreased slightly in samples which were synthesized at 40 and $80{ }^{\circ} \mathrm{C}$ pre-reaction temperatures and calcined at $300{ }^{\circ} \mathrm{C}$, while even the most severe peak decreased significantly in samples calcined at $700{ }^{\circ} \mathrm{C}$. The peak intensities of the samples synthesized under $\mathrm{Ca} / \mathrm{Si}: 0.83$, that is tobermorite synthesis conditions, have 


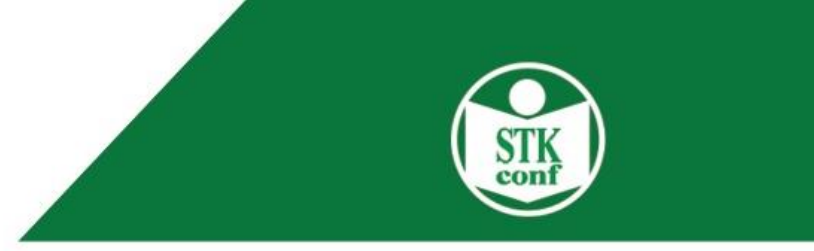

15-17 November 2019

Rotterdam, Netherlands

been proved to be higher than the peak intensities of samples synthesized under xonotlite synthesis conditions of $\mathrm{Ca} / \mathrm{Si}$ : 1.00 . In comparison with the $\mathrm{I} / \mathrm{I}_{\mathrm{o}}$ : 100 peaks, xonotlite has been found to pass into a more fragile calcium silicate structure, $11 \AA$ tobermorite, with a decrease in $\mathrm{Ca} / \mathrm{Si}$ ratio. In this case, it can be interpreted that the silicon content in the structure is high. The decrease in $\mathrm{Ca} / \mathrm{Si}$ ratio did not cause a significant difference in $2 \Theta$ value of sharp peak. In other words, the increase in the pre-reaction temperature led to a small increase in the peak intensity of xonotlite raw material and to a small decrease in tobermorite. The presence of xonotlite and tobermorite reflections in the structure at both ratios can be interpreted as the presence of xonotlite-tobermorite mixture in all samples. The sharp reflection of [002] plane reflection found around 2Ө: $\sim 6^{\circ}$ representing tobermorite, also observed in conditions of $\mathrm{Ca} / \mathrm{Si}$ : 1.00 at 40 and $60{ }^{\circ} \mathrm{C}$ pre-reaction temperature represents tobermorite impurity in xonotlite phase. It is known that silicon materials in the literature are exhibited in the range of $2 \theta: 20-30^{\circ}$ in the studies of silicon materials (Figure 4).

\section{Conclusions}

In this study, calcium silicates (C-S) which can be used as additives, fillers or specially shaped products in thermal insulation due to their mechanical and microstructural properties were investigated. The synthesis of tobermorite $(\mathrm{Ca} / \mathrm{Si}: 0.83)$ and xonolite $(\mathrm{Ca} / \mathrm{Si}: 1.00) \mathrm{C}-\mathrm{S}-\mathrm{H}$ minerals was carried out successfully. Phase transformations at $300{ }^{\circ} \mathrm{C}$ and $700{ }^{\circ} \mathrm{C}$ were determined by thermal TGA/DTA curves. It was determined that mass loss up to $600{ }^{\circ} \mathrm{C}$ in TGA outputs was caused by both - $\mathrm{OH}$ removal and $\mathrm{CaOH}$ degradation which may occur in the structure detected in XRD patterns. In XRD graphs, I/ $\mathrm{I}_{0}: 100$ peak of $\mathrm{C}-\mathrm{S}-\mathrm{H}$ minerals was observed in all samples, while other plane reflections were not very clear. Compared to the $\mathrm{I} / \mathrm{I}_{\mathrm{o}}$ : 100 peaks, it was found that xonotlit was passed to $11 \AA$ tobermorite structure which is a more fragile calcium silicate structure with the decrease of $\mathrm{Ca} / \mathrm{Si}$ ratio. It has been proved that the peak intensities of the samples synthesized under tobermorite synthesis conditions are higher than the peak intensities of samples synthesized under xonotlite synthesis conditions.

\section{Acknowledgment}

This work was financially supported by Gazi University (Code: BAP 06/2017-15 and 06/2019-18)

\section{References}

[1] Picker, A., Nicoleau, L., Nonat, A., Labbez, C., and Cölfen, H. (2014). Identification of binding peptides on calcium silicate hydrate: A novel view on cement additives. Advanced Materials, 26(7), pp. 1135-1140.

[2] Hall, M. R. (2010). Materials for Energy Efficiency and Thermal Comfort in Buildings Germany: Woodhead Publishing, pp. 193-228.

[3] Ingham, J. P. (2012). Geomaterials under the microscope London: Academic Press, pp. 121-127.

[4] Carabba, L., Emrys Scarponi, G., Tugnoli, A., Chiara Bignozzi, M., and Moricone, R. (2018). Investigation of lightweight geopolymer mortars as fireproofing coatings. 
[5] Erdoğdu, Ş. and Kurbetçi, Ş. Betonun performansına sağladıkları etkinlik açısından kimyasal ve mineral katk maddeleri.

[6] Richardson, I. G. (2008). The calcium silicate hydrates. Cement and concrete research, 38(2), pp. 137-158.

[7] Wu, H., Yang, J., Ma, H., and Wang, M. (2013). Preparation of acicular wollastonite using hydrothermal and calcining methods. Integrated Ferroelectrics, 146(1), pp. 144-153.

[8] Meller, N., Hall, C., and Phipps, J. S. (2005). A new phase diagram for the $\mathrm{CaOA} 2 \mathrm{O} 3 \mathrm{SiO} 2 \mathrm{H} 2 \mathrm{O}$ hydroceramic system at $200^{\circ} \mathrm{C}$. Materials Research Bulletin, 40(5), pp. 715-723.

[9] Gordienko, P. S., Mikhailov, M. M., Banerjee, S., Sharma, Y. C., Yarusova, S. B., Zhevtun, I., Vlasov, V., Shabalin, I., and Sushkov, Y. V. (2017). Effect of annealing conditions on the structure, phase and granulometry composition, and reflectance spectra and their changes on irradiation for calcium silicate powders. Materials Chemistry and Physics, 197, pp. 266-271.

[10] Galvánková, L., Másilko, J., Solný, T., and Štěpánková, E. (2016). Tobermorite synthesis under hydrothermal conditions. Procedia Engineering, 151, pp. 100-107.

[11] Singh, S. P. and Karmakar, B. (2011). Mechanochemical synthesis of nano calcium silicate particles at room temperature. New journal of glass and ceramics, 1(2), pp. 49-52.

[12] Diamond, S., Dolch, W., and White, J. L. (1964). Studies on tobermorite-like calcium silicate hydrates. Highway Research Record, pp. 62

[13] Kapeluszna, E., Kotwica, Ł., Różycka, A., and Gołek, Ł. (2017). Incorporation of Al in CASH gels with various $\mathrm{Ca} / \mathrm{Si}$ and $\mathrm{Al} / \mathrm{Si}$ ratio: Microstructural and structural characteristics with DTA/TG, XRD, FTIR and TEM analysis. Construction and Building Materials, 155(643-653.

[14] Sasaki, K., Masuda, T., Ishida, H., and Mitsuda, T. (1996). Structural degradation of tobermorite during vibratory milling. Journal of the American Ceramic Society, 79(6), pp. 1569-1574.

[15] Internet: $\quad$ Tobermorite Mineral Data http://webmineral.com/data/Tobermorite.shtml\#.XS0N_Oszapo, Access date: 16.07.2019

[16]Zhao, D., Huo, Q., Feng, J., Chmelka, B. F., and Stucky, G. D. (1998). Nonionic triblock and star diblock copolymer and oligomeric surfactant syntheses of highly ordered, hydrothermally stable, mesoporous silica structures. Journal of the American Chemical Society, 120(24), pp. 6024-6036.

[17]Øye, G., Sjöblom, J., and Stöcker, M. (2001). Synthesis, characterization and potential applications of new materials in the mesoporous range. Advances in Colloid and Interface Science, 89, pp.439-466.

[18] Grangeon, S., Claret, F., Lerouge, C., Warmont, F., Sato, T., Anraku, S., Numako, C., Linard, Y., and Lanson, B. (2013). On the nature of structural disorder in calcium silicate hydrates with a calcium/silicon ratio similar to tobermorite. Cement and Concrete Research, 52, pp. 31-37. 
[19] Hsiang, H.-I., Chen, W.-S., and Huang, W.-C. (2016). Pre-reaction temperature effect on $C-S-H$ colloidal properties and xonotlite formation via steam assisted crystallization. Materials and Structures, 49(3), pp. 905-915. 